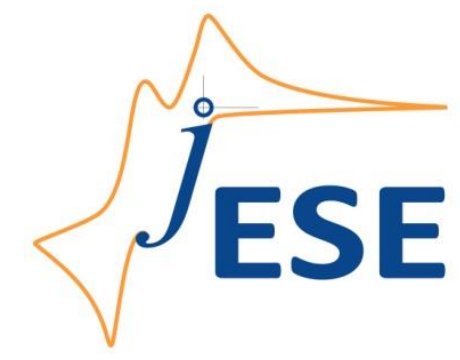

Open Access : : ISSN 1847-9286 www.jESE-online.org

Review

\title{
A review of liquid metal anode solid oxide fuel cells
}

\author{
ALIYA TOLEUOVA*,**, VLADIMIR YUFIT***, STEFAAN SIMONS*,****, \\ WILLIAM C. MASKELL $* * * *$, DANIEL J. L. BRETT*,ه
}

*Electrochemical Innovation Lab, Department of Chemical Engineering, University College London, Torrington Place, London WC1E 7JE, UK

**School of Engineering, Nazarbayev University, 53 Kabanbay Batyr Ave, Astana 010000, Republic of Kazakhstan

***Department of Earth Science and Engineering, Imperial College London, London SW7 2AZ, UK

****International Energy Policy Institute, UCL Australia, 220 Victoria Square, Adelaide, Australia

Corresponding Author: E-mail: d.brett@ucl.ac.uk; Tel.: +44(0)207 679 3310; Fax: +44(0)207 3832348

Received: December 31, 2012; Published: June 12, 2013

\begin{abstract}
This review discusses recent advances in a solid oxide fuel cell (SOFC) variant that uses liquid metal electrodes (anodes) with the advantage of greater fuel tolerance and the ability to operate on solid fuel. Key features of the approach are discussed along with the technological and research challenges that need to be overcome for scale-up and commercialisation.
\end{abstract}

\section{Keywords}

Solid oxide fuel cell; liquid metal anode; direct carbon fuel cell.

\section{Introduction}

The world's growing energy demands have led to increasing environmental and resource availability concerns. In this regard, stabilization of increasing anthropogenic $\mathrm{CO}_{2}$ emissions is one of the most urgent issues associated with global climate change. According to the International Energy Agency (IEA), fossil fuels will remain the primary energy sources, representing more than $75 \%$ of the overall growth in energy use from 2007 to 2030 [1]. Moreover, carbon-free energy technologies are unable to meet global demands in the foreseeable future [2]. Therefore, continued use of fossil fuels in a 'low-carbon economy' necessitates the reduction of $\mathrm{CO}_{2}$ emissions by improving process efficiency. Notwithstanding the reduction in greenhouse gas emissions brought about by high efficiency, fuel cells generate carbon dioxide free from diluting nitrogen which can be sequestered at lower cost compared with the exhaust products from most electricity generation based upon combustion of fossil fuels. 
While coal remains the most available and abundant fuel source around the world $160 \%$ of all global sources), highly efficient fuel technologies are required to minimize the severe environmental impact of electric energy production from coal [3]. In this regard, several studies [4-7] have presented novel concepts for the direct electrochemical oxidation of carbon (coal or biomass) for highly efficient electricity generation using Liquid Metal Electrode Solid Oxide Fuel Cells (LME SOFCS). This new class of fuel cell offers the advantage of high efficiency with the benefits of greater fuel tolerance, the concept being particularly well suited to the direct use of solid fuel.

High temperature solid oxide fuel cells (SOFC) are highly efficient electrochemical energy conversion devices capable of converting the chemical energy stored in gaseous fuels (including hydrogen, alkanes, alcohols, alkenes, alkynes, ketones, etc.) into electrical power [8]. The operational efficiency of such systems is higher than conventional heat engines since the process is electrochemical and not constrained by the Carnot efficiency limitation. Typical efficiencies obtained from SOFCs are in the range of $50-60 \%$ (LHV). The technology is highly scalable with systems in the hundreds of kilowatts demonstrated. The SOFC is increasing attention as a clean and efficient power-generating technology. However, durability and performance degradation due to impurities contained in hydrocarbon fuels, such as sulfur and other trace elements, continue to be a concern [4]. Contaminants may react with the anode materials via various mechanisms to decrease electrochemical reaction rates by increasing charge transfer resistance and result in mechanical failure of materials [9]. In order to mitigate the influence of fuel impurities on cell degradation, the supplied fuel should undergo pretreatment using a variety of adsorbents and filters [10]. Alternatively, substantial improvements in anode materials are necessary to make the anode more tolerant of fuel contaminants. One approach to achieving this is to use a liquid metal anode solid oxide fuel cell (LMA SOFC). This allows operation on a variety of carbonaceous fuels gaseous or solid, while remaining highly tolerant towards fuel contaminants.

Some of the earliest work on liquid metal electrodes was reported by Cell Tech Power, who used liquid tin as their anode material of choice $[5,6,11,12]$ and achieved a power density of 170 $\mathrm{mW} \mathrm{cm} \mathrm{cm}^{-2}$ on hydrogen and JP-8 fuel [4]. The projected efficiency of such a system operating on coal is $61 \%$ [13].

However, LMA SOFC technology is not yet well-understood. The nature of the cells makes experimental investigation challenging and the processes occurring in the melt are difficult to study in situ. There is a certain inconsistency between published studies in terms of the experimental arrangement and little is known about the mechanism of fuel oxidation within the liquid metal media.

Being a comparatively novel system, LMA SOFC technology is some way from being fully commercialized due to technical challenges unique to this class of fuel cell. The objective of this review paper is therefore to provide a summary of emerging LMA SOFC technologies, discuss the advantages of the approach and set out the research and technological challenges that need to be addressed and overcome.

\section{Background to fuel cells}

Fuel cells are electrochemical energy conversion devices that convert chemical energy in fuel directly into electricity (and heat) without involving the process of combustion. The technology is highly efficient, can be applied to a range of fuels (depending upon the type of fuel cell), quiet in operation (the fuel cell itself has no moving parts) and scalable from $\mathrm{mW}$ to MW. As such, fuel 
cells are considered as one of the most promising technological solutions for sustainable power generation. Fuel cells can be used in a broad range of applications, including: transportation, residential combined heat and power (CHP), large scale distributed power generation and battery replacement uses.

Fuel cells come in a range of architectures and material sets, but central to all is the electrolyte onto which there is attached the anode and cathode electrodes on each side. Figure 1 illustrates the simplistic operation of a fuel cell (using the SOFC as an example). The cell is constructed from two porous electrodes separated by an electrolyte. Oxygen or air is supplied to the cathode (also referred to as the 'air electrode') where electrochemical reduction of the oxygen takes place to form oxide ions $\left(\mathrm{O}^{2-}\right)$ that migrate through the electrolyte, to the anode (also referred to as the 'fuel electrode'), and oxidize the fuel (hydrogen in this case) releasing water, heat and electrons that travel around an external circuit to the cathode and do useful work.

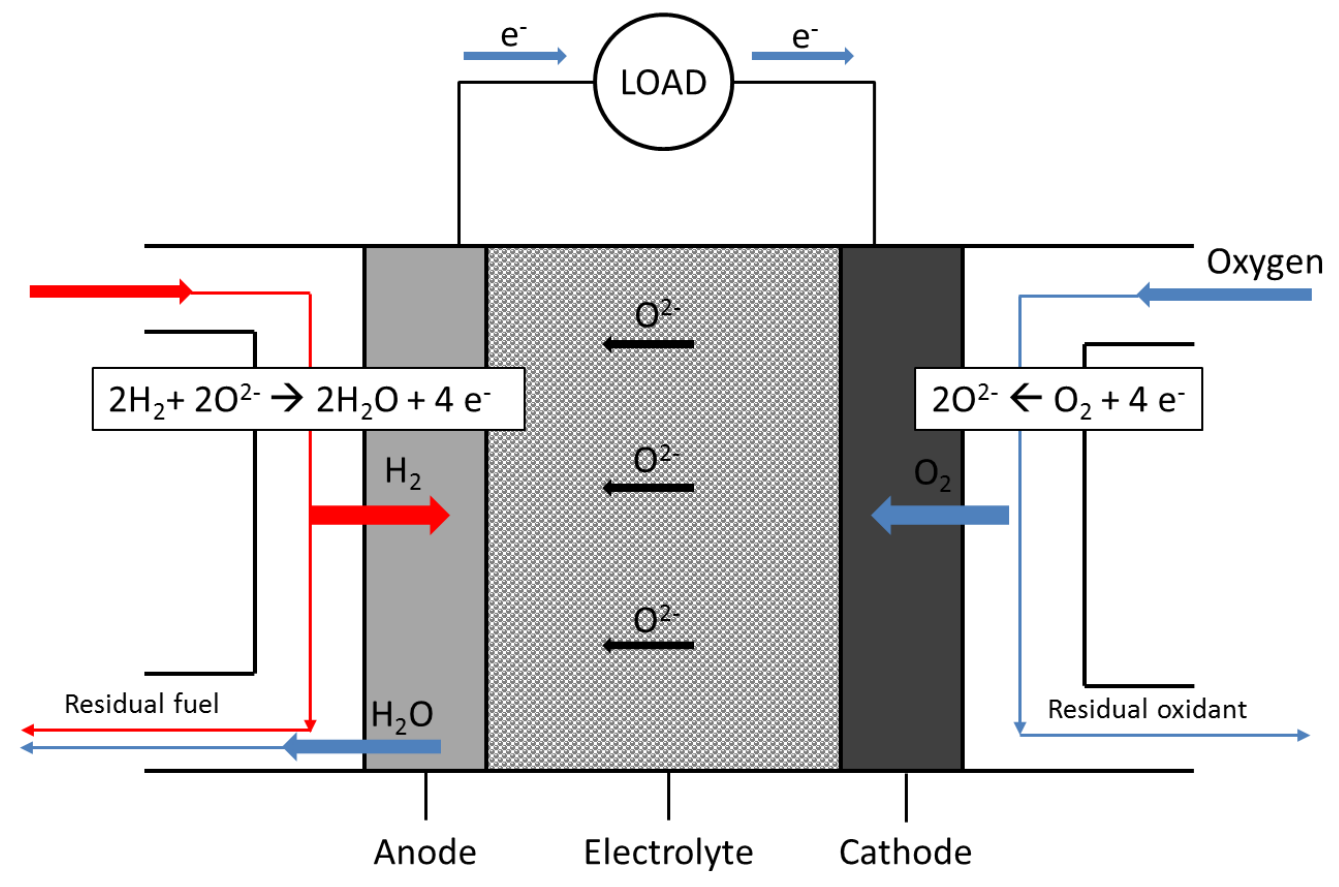

Figure 1. Schematic operation of an individual fuel cell (taking a solid oxide fuel cell as an example).

\section{Different types of fuel cells}

Fuel cell types vary from one to another in operating parameters and technical characteristics (e.g. power density, efficiency, etc.). However, the fundamental feature of the fuel cell which is different, and indeed names the fuel cell type, is the electrolyte. There are at least five main fuel cell types: Phosphoric Acid Fuel Cell (PAFC), Proton Exchange Membrane Fuel Cell (PEMFC), Alkaline Fuel Cell (AFC), Molten Carbonate Fuel Cell (MCFC) and Solid Oxide Fuel Cell (SOFC). In the first two types, hydrogen ions (protons) flow through the electrolyte from anode to cathode to react with oxygen, and produce water; whereas in the last three types (Alkaline, Molten and Solid Oxide fuel cells) anions $\left(\mathrm{OH}^{-}, \mathrm{CO}_{3}{ }^{2-}, \mathrm{O}^{2-}\right)$ migrate through the electrolyte from cathode to anode to react with fuel and similarly produce water (Figure 2). Fuel cell electrolytes are electronically insulating but ionically conducting, allowing certain types of ions to transport through them. 


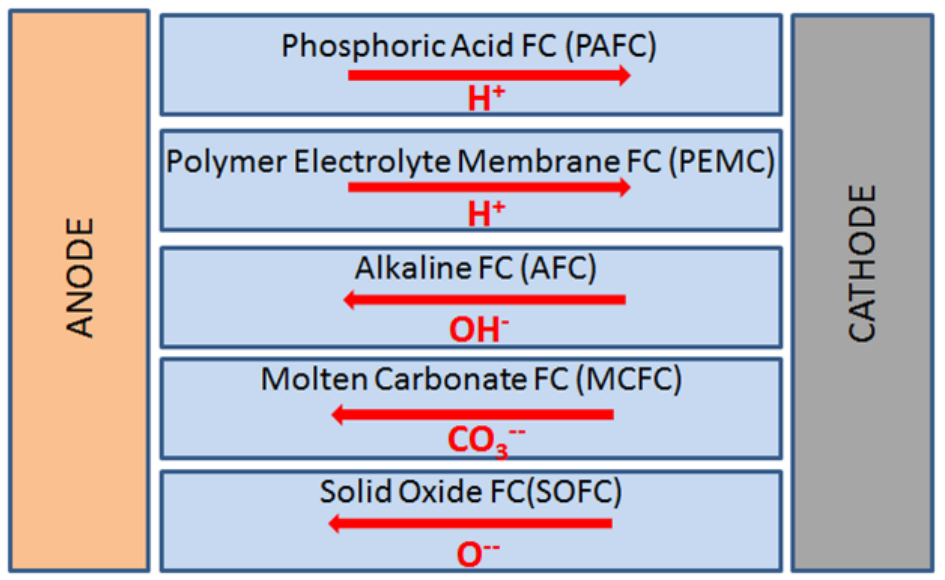

Figure 2. Flow of ions through different fuel cell electrolyte types.

\section{Fuel cell applications}

The most common types of fuel cell systems and their main characteristics, including fuel efficiency, operating temperature, lifetime, etc. are summarised in Table 1. The type of fuel cell and the range of operating temperatures are primarily related to the electrolyte material. Hence, the first three types (AFC, PAFC, and PEMFC) are considered as low temperature fuel cells, and the other two types (MCFC and SOFC) require high temperature. Low temperature fuel cells have the advantage of rapid start-up time but necessitate precious metal electrocatalysts and high purity hydrogen as fuel.

Table 1. Technical characteristics of the five main fuel cell types (1 - [14]; 2 - [15]; 3 -[16])

\begin{tabular}{|c|c|c|c|c|c|c|c|c|c|}
\hline 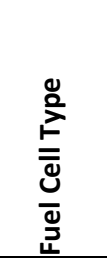 & 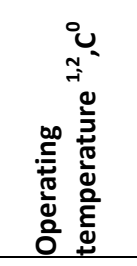 & 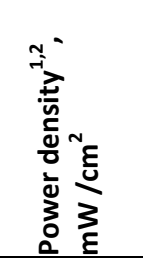 & $\begin{array}{l}m \\
\frac{N}{N} \\
\frac{0}{0} \\
\frac{\pi}{4} \\
\frac{\pi}{0} \\
\frac{0}{2} \\
i\end{array}$ & 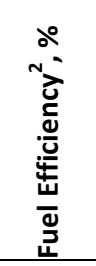 & $\begin{array}{l}-10 \\
\stackrel{1}{0} \\
\frac{1}{0} \\
\frac{0}{0} \\
0 \\
0 \\
0\end{array}$ & 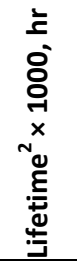 & $\begin{array}{c}\text { Applications }^{2,3} ; \\
\text { Capital Cost }^{2}, \$ / \mathrm{kW}\end{array}$ & Advantages $^{3}$ & Disadvantages $^{3}$ \\
\hline PAFC & $150-200$ & $150-300$ & $\begin{array}{l}400 \mathrm{~kW} \\
100 \mathrm{~kW} \\
\text { module }\end{array}$ & 55 & $\begin{array}{l}\text { Poison } \\
(<1 \%)\end{array}$ & $>40$ & $\begin{array}{l}\text { Distributed Power; } \\
3000 \$ / \mathrm{kW}\end{array}$ & $\begin{array}{l}\text { - Higher temperature } \\
\text { enables CHP; } \\
\text {-Increased tolerance to - } \\
\text { fuel impurities }\end{array}$ & $\begin{array}{l}\text { - Pt catalyst; } \\
\text { - Long start up time; } \\
\text { - Low current and } \\
\text { power; }\end{array}$ \\
\hline PEMFC & $50-100$ & $\begin{array}{c}300-1000 \\
\left(350^{2}\right)\end{array}$ & $<1-100 \mathrm{~kW}$ & $45-60$ & $\begin{array}{l}\text { Poison } \\
\text { (<50ppm) }\end{array}$ & $>40$ & $\begin{array}{l}\text { - Backup power; } \\
\text { - Portable power; } \\
\text { - Distributed gene- } \\
\text { ration; } \\
\text { - Transportation; } \\
\text { - Specialty vehicles; } \\
\text { >200 \$/kW } \\
\end{array}$ & $\begin{array}{l}\text { - Solid electrolyte } \\
\text { reduces corrosion \& } \\
\text { electrolyte mana- } \\
\text { gement problems; } \\
\text { - Low temperature; } \\
\text { - Quick start-up }\end{array}$ & $\begin{array}{l}\text { - Expensive catalysts; } \\
\text { - Sensitive to fuel } \\
\text { impurities; } \\
\text { - Low temperature } \\
\text { waste heat }\end{array}$ \\
\hline AFC & $90-100$ & $150-400$ & 10-100 kW & $40-60$ & $\begin{array}{l}\text { Poison } \\
\text { (<50ppm) }\end{array}$ & $>10$ & $\begin{array}{l}\text { - Military; } \\
\text { - Space; } \\
\text { >200 \$/kW }\end{array}$ & $\begin{array}{l}\text { - Cathode reaction faster - } \\
\text { in alkaline electrolyte, } \\
\text { leads to high } \\
\text { performance; } \\
\text { - Low cost components } \\
\end{array}$ & $\begin{array}{l}\text { - Sensitive to } \mathrm{CO}_{2} \text { in } \\
\text { fuel and air; } \\
\text { - Electrolyte } \\
\text { management }\end{array}$ \\
\hline MCFC & $600-700$ & $100-300$ & $\begin{array}{l}0.3-3 \mathrm{MW} \\
300 \mathrm{~kW} \\
\text { module }\end{array}$ & $60-65$ & Fuel & $>40$ & $\begin{array}{l}\text { - Electric utility; } \\
\text { - Distributed power } \\
\text { generation; } \\
1000 \$ / \mathrm{kW}\end{array}$ & $\begin{array}{l}\text { - High efficiency; } \\
\text { - Fuel flexibility; } \\
\text { - Can use a variety of } \\
\text { catalysts; } \\
\text { - Suitable for CHP; }\end{array}$ & $\begin{array}{l}\text { - High temperature } \\
\text { corrosion and } \\
\text { breakdown of cell } \\
\text { components; } \\
\text { - Long start-up time; } \\
\text { - Low power density }\end{array}$ \\
\hline SOFC & $800-1000$ & $250-350$ & $1 \mathrm{~kW}-2 \mathrm{MW}$ & $55-65$ & Fuel & $>40$ & $\begin{array}{l}\text { - Baseload power } \\
\text { generation; } \\
\text { - Auxiliary power; } \\
\text { - Electric utility; } \\
\text { - Distributed } \\
\text { generation; } \\
1500 \$ / \mathrm{kW}\end{array}$ & $\begin{array}{l}\text { - High efficiency; } \\
\text { - Fuel flexibility; } \\
\text { - Can use a variety of } \\
\text { catalysts; } \\
\text { - Solid electrolyte; } \\
\text { - Suitable for CHP\&CHHP; } \\
\text { - Hybrid/GT cycle }\end{array}$ & $\begin{array}{l}\text { - High temperature } \\
\text { corrosion and } \\
\text { breakdown of cell } \\
\text { components; } \\
\text { - High temperature } \\
\text { operation requires } \\
\text { long start up time }\end{array}$ \\
\hline
\end{tabular}




\section{Liquid Metal Electrode Electrochemical Systems}

The generic construction of a LMA SOFC is illustrated in Figure 3. The arrangement is ostensibly identical to a conventional SOFC except that the anode is a molten metal. Fuel is fed to the electrode and oxidized products are generated in the same way. The difference is that both gaseous and solid fuel can be fed directly and effectively converted with no pre-treatment stage.

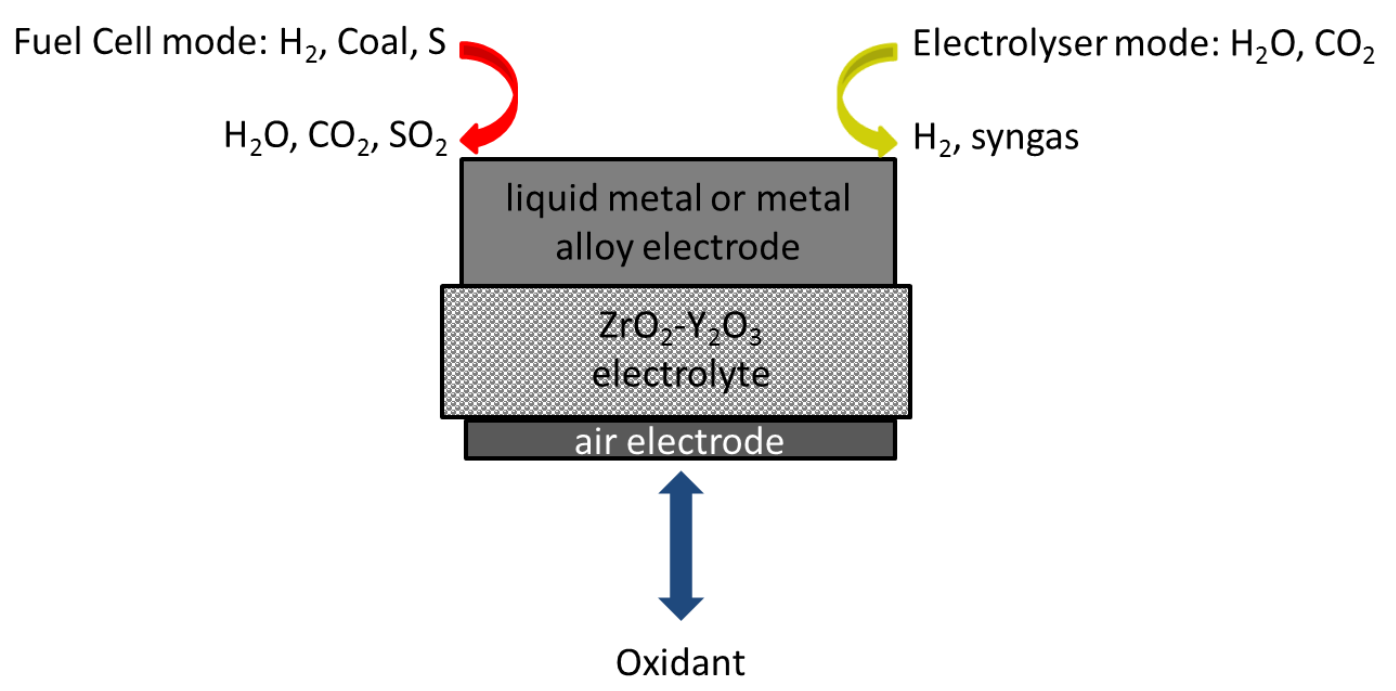

Figure 3. Operation of liquid metal electrode reactor in fuel cell and electrolyser mode.

Figure 3 also shows the potential for operation in electrolyser mode. This concept has the cell fed with $\mathrm{CO}_{2}$ and steam $\left(\mathrm{H}_{2} \mathrm{O}\right)$ that are electrochemically converted to synthesis gas (a mixture of hydrogen and carbon monoxide), that can be used to make liquid fuel (i.e. via the Fischer-Tropsch process) or used in a fuel cell directly [17].

\section{Liquid Metal Anode SOFCS}

The liquid metal electrode resides in a layer between the fuel chamber (gaseous or solid fuel) and the solid electrolyte (Figure 4). The oxygen reduction reaction occurs at the cathode/electrolyte interface resulting in oxygen ions, which then migrate though the solid electrolyte, typically represented by yttria-stabilised zirconia (YSZ), to the liquid metal anode. The $\mathrm{O}^{2-}$ ions react electrochemically with the liquid metal, generating metal oxide which is the active species for the oxidation of the fuel (gaseous or solid - carbon and hydrogen in the diagram), producing carbon dioxide or water respectively. However, the exact mechanism occurring and the species involved in the liquid metal anode media are not well defined and depend upon the metal used.

The molten metal blocks direct contact of electrolyte with gaseous impurities and hence reduces electrolyte degradation by inhibiting the reaction between contaminants and electrolyte [4]. Moreover, the fuel contaminants can become a fuel source themselves as they undergo electrochemical oxidation. All of the electrolyte surface in contact with the anode is available to supply a flux of oxide ions for reaction - there is no need to engineer a complex ceramic metal (cermet) electrode with optimized triple phase boundary (TPB) as is necessary in conventional SOFCs $[18,19]$. 


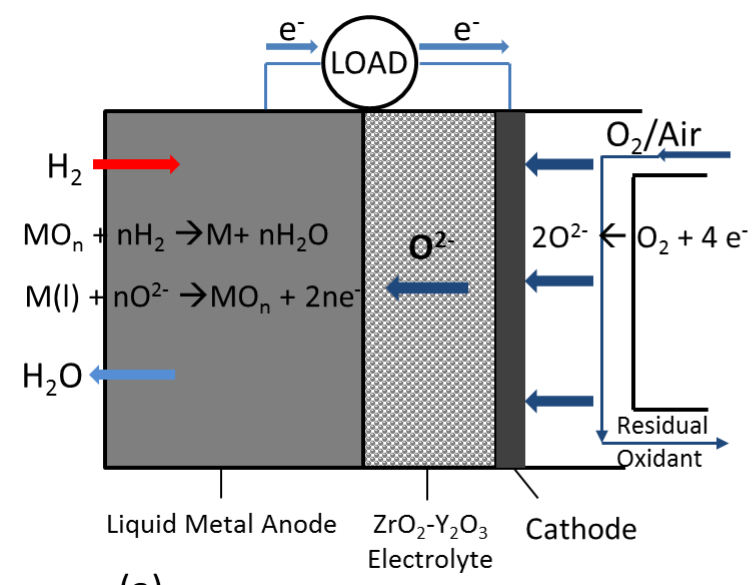

(a)

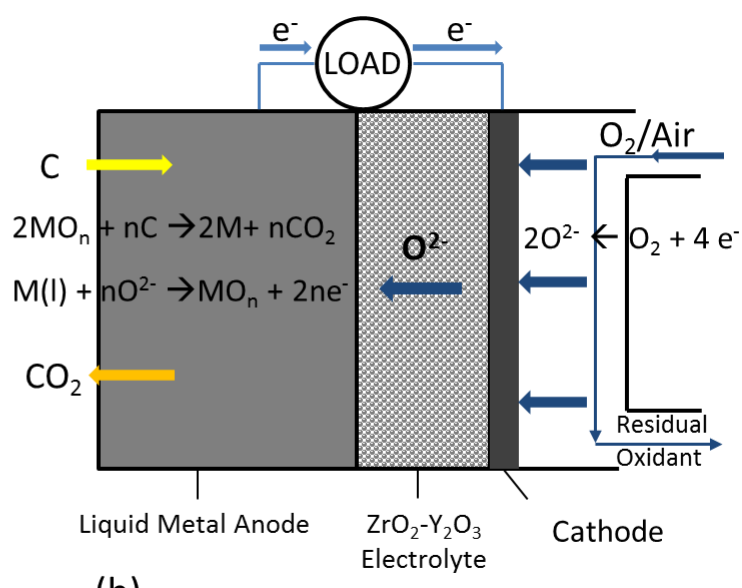

(b)

Figure 4. Schematic showing operation of LMA SOFC with

(a) hydrogen and (b) solid carbon, as the fuel.

\section{Operation of Liquid Metal Anode SOFCS}

The liquid metal anode acts as an intermediary for the oxidation of fuel [4]. Taking a molten metal (M) and hydrogen as a fuel, the reactions at the LMA-SOFC anode follows the generic mechanism:

$$
\begin{aligned}
& \mathrm{M}+\mathrm{xO}^{2-} \rightarrow \mathrm{M}\left[\mathrm{O}_{x}\right]_{M}+2 x \mathrm{e}^{-} \\
& \mathrm{xH}_{2}+\mathrm{M}\left[\mathrm{O}_{\mathrm{x}}\right]_{M} \rightarrow \mathrm{M}+\mathrm{xH}_{2} \mathrm{O}
\end{aligned}
$$

Reaction (1) proceeds at the liquid anode-electrolyte interface, whereas reaction (2) occurs at the fuel-anode interface. The oxide ions $\left(\mathrm{O}^{2-}\right)$ are delivered from the cathode via the electrolyte. $\left[\mathrm{O}_{\mathrm{x}}\right]_{\mathrm{M}}$ is a state of oxygen within the liquid metal anode. The state of oxygen in the metal varies with operating conditions, and hence ' $x$ ' is used to represent this uncertainty. When using tin, oxygen may form oxide or suboxide or remain dissolved in the melt [20]. The state of oxygen may vary, though it has no particular effect on the overall reaction, which is the sum of Reactions (1) and (2):

$$
\mathrm{H}_{2}+\mathrm{O}^{2-} \rightarrow \mathrm{H}_{2} \mathrm{O}+2 \mathrm{e}^{-}
$$

Reaction (3) is applicable to any liquid metal anode SOFC system including Sn or Cu [21].

\section{Thermodynamics of LMA SOFC operation}

The maximum electrical voltage generated by an electrochemical system can be determined via the standard equilibrium electrode potential $\left(E_{\text {eq }}\right)$, expressed by the Nernst Equation (1) as follows:

$$
E_{e q}=E^{0}+\frac{R T}{n F} \sum_{\mathrm{i}} v_{\mathrm{i}} \ln a_{\mathrm{i}}
$$

Equation (1)

Where $a_{\mathrm{i}}$ and $v_{\mathrm{i}}$ are the activities (fugacities for gases) and stoichiometric factors of the species $\mathrm{i}$ (the stoichiometric factors $v_{\mathrm{i}}$ taking positive and negative values for oxidised and reduced species respectively), $R$ is the molar gas constant, $8.314 \mathrm{~J} \mathrm{~mol}-1 K 1, \mathrm{~T}$ is absolute temperature and $E^{\circ}$ is the standard electrode (equilibrium) potential of the reaction that can be defined from the equation (2):

$$
E^{0}=\frac{-\Delta G_{r}^{0} R T}{n F}
$$

Equation (2) 
where $\Delta G_{r}^{0}$ is the Gibbs free energy change of electrochemical reaction, $n$ - number of electrons transferred during electrochemical reaction and $F$ is Faraday's constant, $96,485 \mathrm{C} \mathrm{mol}^{-1}$.

Figure 5 shows the standard equilibrium potentials of several metal-metal oxide couples as a function of temperature. The data for the figure was generated using the chemical reaction and equilibrium software HSC Chemistry 6.1 (Outotec, Finland).

It can be seen that the cell voltage is expected to decrease with increasing temperature, as a result of the negative entropy change associated with the reactions. However, the voltage obtained under operating conditions (with a net current flowing) is difficult to predict. In addition to the usual loss mechanisms associated with reaction kinetics, ohmic and mass transport limitations, cell voltage will depend on the actual reaction at the anode: whether it is directly with dissolved fuel or the oxidation of the metal to oxide (electrochemical reaction) followed by oxidation of the hydrogen by the oxide (chemical reaction).

If the reaction is directly with the fuel then conventional fuel cell reaction OCVs will hold, which are generally higher than those for the reaction with the metal. Therefore, from a thermodynamic perspective, it may be preferable for the metal to have a low affinity for oxygen and a high solubility of fuel and oxygen.

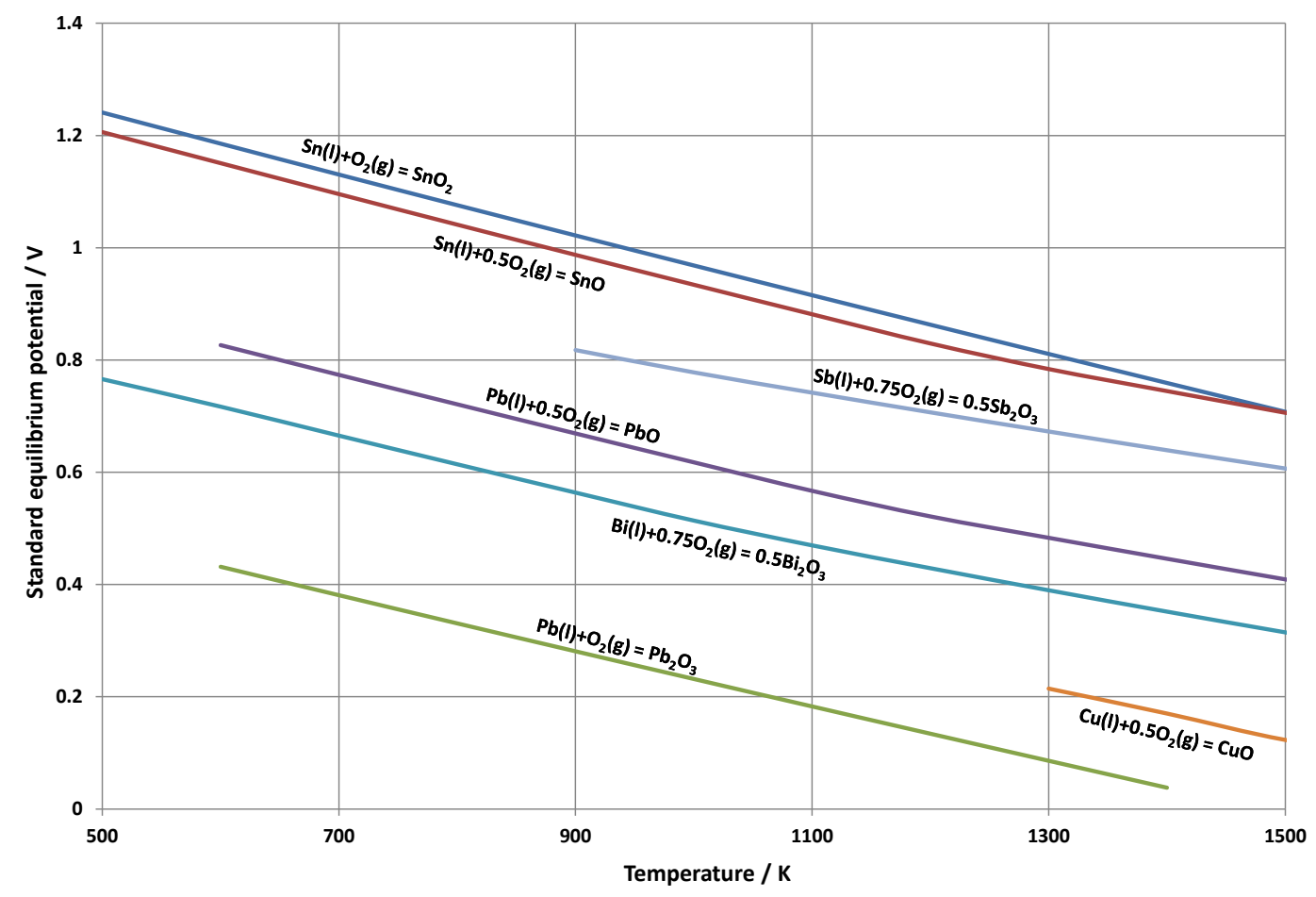

Figure 5.Effect of temperature on standard equilibrium cell potentials for various metal oxidation reactions.

\section{Battery Effect}

The use of LMAs can have an additional positive impact on fuel cell performance by creating the so-called 'battery' buffering effect. It is well known that SOFCs (similar to other fuel cells) can be detrimentally affected by power demand surges during operation, since such surges can cause fuel starvation, which in turn may cause irreversible structural changes at the electrodes. The presence of a certain amount of LMA acts as a metal-oxygen battery, where the metal itself is oxidised to provide sufficient load $[4,5,7]$. The oxidised metal can be reduced again by the fuel fed into the anode when normal load is resumed. 


\section{Liquid Tin Anode SOFC}

Liquid tin anode SOFCs (LTA SOFC) have been demonstrated with a variety of fuels including gaseous, solid and liquid carbonaceous fuels that did not require any processing, reforming or pretreatment to remove sulfur. The power density reported was $>160 \mathrm{~mW} \mathrm{~cm}^{-2}$ with hydrogen, and $120 \mathrm{~mW} \mathrm{~cm}^{-2}$ with JP-8 fuel[20]. Operated at $900{ }^{\circ} \mathrm{C}$, a liquid tin layer of $6 \mathrm{~mm}$ was exposed to humidified $\mathrm{H}_{2}$ gas $\left(3 \% \mathrm{H}_{2} \mathrm{O}\right)$. From the analysis of transient characteristics time, the oxygen (oxide) diffusion coefficient of $1 \times 10^{-3} \mathrm{~cm}^{2} \mathrm{~s}^{-1}$ was derived from test results. The value differs significantly from previously measured literature values [20]. Oxide diffusivity is one of the most critical fundamental parameter that determines cell performance. Inconsistencies in literature reported values call for further work to develop robust methods for the determination of this parameter.

\section{Physical and chemical properties of tin}

Abernathy et al. make the case for tin as an ideal metal for LMA SOFCs [4]. A comparison table (Table 2) summarises basic physical properties and abundances of various metals that can be used as a liquid anode. The metal should have relatively low melting point (simplifying operational conditions) and high boiling point. Tin has a low vapour pressure $\left(9.87 \times 10^{-4} \mathrm{~Pa}\right.$ at $\left.1000{ }^{\circ} \mathrm{C}\right)$ and hence, low volatility [12], i.e. the anode is not vaporised into the fuel exit stream during operation. Being technically easier to operate with, Sn remains the most commonly used anode material for such LA SOFC systems, though some researchers are seeking better anode materials and suggest the use of metal alloys based upon tin.

Such factors as metal abundances in the Earth's crust, annual production and associated prices also have to be taken into consideration. Research studies so far have shown results working with tin, copper and bismuth. Other metals may not be suitable due to hazards (Sb), high price (Ag) or low abundance (In).

Table 2. Common metals properties and abundances, prices (adapted from [4])

\begin{tabular}{lccccc}
\hline Metal & $\boldsymbol{T}_{\mathrm{m}} /{ }^{\circ} \mathbf{C}$ & $\boldsymbol{T}_{\mathrm{b}} / \mathbf{}^{\circ} \mathbf{C}$ & $\begin{array}{c}\text { Price*, } \\
\mathbf{\$} / \mathbf{k g}\end{array}$ & $\begin{array}{c}\text { Abundance in Earth's } \\
\text { crust, } \mathbf{p p m}\end{array}$ & $\begin{array}{c}\text { Reported experimental studies } \\
\text { using metal and/or metal alloys }\end{array}$ \\
\hline Aluminum & 660 & 2520 & 1.7 & 83,000 & - \\
\hline Antimony & 631 & 1587 & 5.0 & 0.20 & {$[22],[23]$} \\
\hline Bismuth & 271 & 1564 & 16.3 & 0.063 & {$[21],[24-27]$} \\
\hline Cadmium & 321 & 767 & 2.7 & 0.10 & [21] \\
\hline Copper & 1085 & 2563 & 5.2 & 79 & [23] \\
\hline Indium & 157 & 2073 & 390 & 0.05 & Pb - [23];Sn-Pb alloy-[25]; \\
\hline Lead & 328 & 1750 & 1.7 & 7.9 & Sn-Pb-Bi alloy-[25], \\
\hline Tin & 232 & 2603 & 13.9 & 2.5 & - \\
\hline Silver & 962 & 2163 & 471 & 0.079 & [11-13], [20], [24], [26-28] \\
\hline Zinc & 420 & 907 & 1.7 & 79 & - \\
\hline *The metal prices are taken from US Geological Survey Minerals Information Team, Mineral Commodity Summaries 2010
\end{tabular}

The following table (Table 3) shows the change of thermophysical properties of tin at a range of temperatures, including the solubility of oxygen, hydrogen and sulfur. Electrical resistivity of tin at $1000{ }^{\circ} \mathrm{C}$ has a reasonable value of $67.1 \mu \Omega \mathrm{cm}$ compared to the resistivity of nickel $(53.1 \mu \Omega \mathrm{cm})$ used in conventional ceramic metal (cermet) SOFC anodes [12]. 
Table 3. Thermophysical properties of tin (adapted from [4])

\begin{tabular}{lll}
\hline Property & Temperature, ${ }^{\circ} \mathrm{C}$ & Value \\
\hline Surface tension & 232 & $5.44 \mathrm{~m} \mathrm{~N} \mathrm{~cm}^{-1}$ \\
\hline Viscosity & 232 & $1.85 \mathrm{~m} \mathrm{~N} \mathrm{~m}^{-2}$ \\
\hline Expansion on melting & 232 & $2.3 \%$ \\
\hline \multirow{2}{*}{ Density } & 800 & $6580 \mathrm{~kg} \mathrm{~m}^{-3}$ \\
\cline { 2 - 3 } Resistivity & 1000 & $6480 \mathrm{~kg} \mathrm{~m}^{-3}$ \\
\hline \multirow{2}{*}{ Gas solubility-oxygen } & 800 & $62.1 \mu \Omega \mathrm{cm}$ \\
\hline \multirow{2}{*}{ Gas solubility- hydrogen } & 1000 & $67.1 \mu \Omega \mathrm{cm}$ \\
\hline \multirow{2}{*}{ Gas solubility - sulfur } & 536 & $0.000018 \mathrm{wt} \%$ \\
\cline { 2 - 3 } & 750 & $0.0049 \mathrm{wt} \%^{3}$ \\
\hline
\end{tabular}

The density of tin and nickel at room temperature are $7.28 \mathrm{~g} \mathrm{~cm}^{-3}$ and $8.90 \mathrm{~g} \mathrm{~cm}^{-3}$ respectively. This makes tin an even more preferable metal on the basis of weight [12]. High solubility of sulfur in the melt is an attractive property of tin, allowing 'dirty' fuels to be used without sulfur removal or fuel reforming.

Fuels Investigated

Various fuels have been studied for LTA SOFCs including biodiesel [5], military fuels, such as JP-8 $[6,11,13]$, gasoline, methane, etc. All these studies confirm the LTA SOFC fuel flexibility. Figure 6 summarises measured efficiency of LTA SOFC operated on different fuels [6].

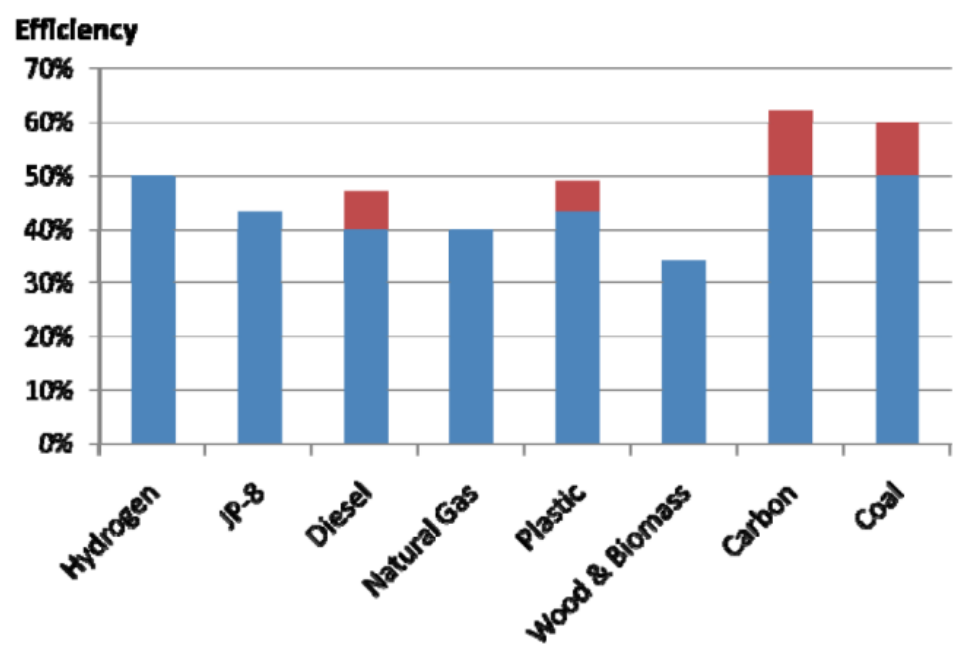

Figure 6. Measured efficiency of LTA SOFC over the range of fuels [6]

\section{Electrochemical Characterisation of LTA SOFCS}

The first studies on LTA SOFC developed by Cell Tech Power LLC were reported in 1998 [12] and subsequently mainly focused on applying LTA SOFC for distributed power generation using natural gas. The next step was to test alternative fuels such as waste plastics and military logistic fuels (e.g. JP-8) applicable for portable applications, followed by studies where biomass and coal are 
considered to be directly converted in LTA SOFC. Tao et al. [12] initially developed the Gen 3.0 cell and stack and demonstrated a power density of $40 \mathrm{~mW} \mathrm{~cm}$-2 with JP-8 fuel. Cell performance was significantly improved in the next generation cell - Gen 3.1, which was lighter by a factor of four. The operational power density was $120 \mathrm{~mW} \mathrm{~cm}^{-2}$ with JP-8 fuel that contained $1400 \mathrm{ppm}$ of sulphur [12]. This study confirmed the operation of LTA SOFC without fuel desulfurization or preprocessing. To overcome existing drawbacks of the previous cell design (Gen 3.0) an alumina porous separator was introduced to increase fuel mass transport to liquid tin. Prior to testing with JP-8, Gen 3.1 was tested with hydrogen to ensure proper cell operation (Figure 7 (left)).
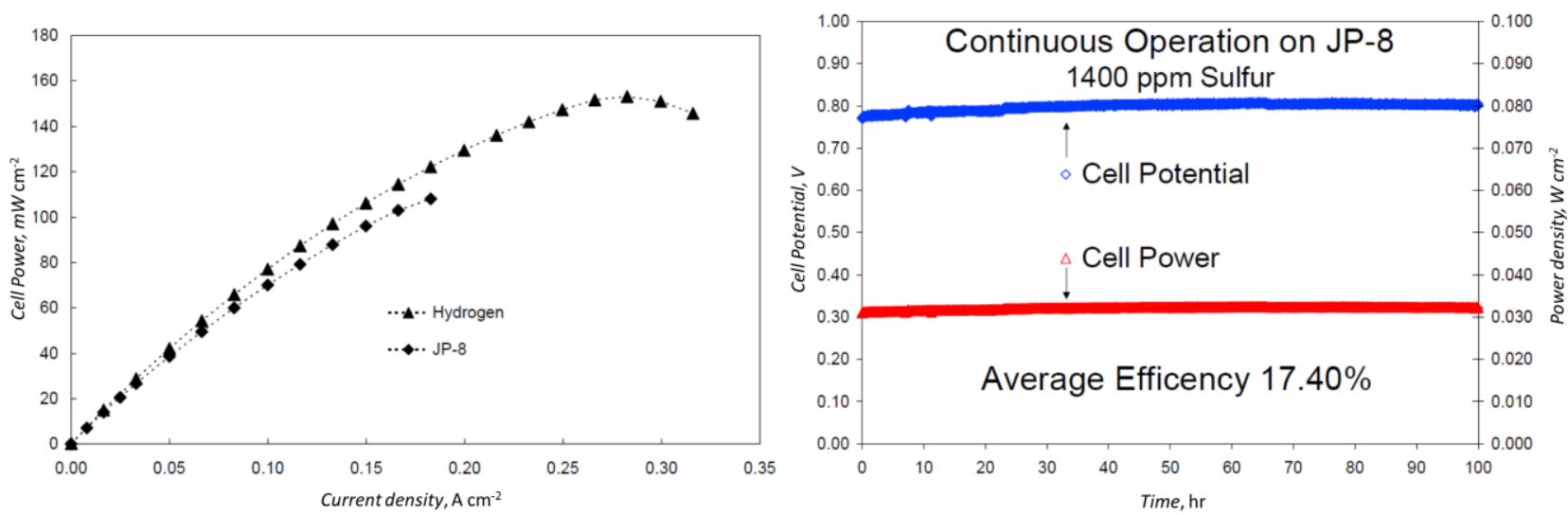

Figure 7. Power curves for tin based cells operating on hydrogen and JP-8 (left); durability test on JP-8 $(V, W)$ (right) [12]

At equal operating conditions the cell fed with JP-8 showed $70-80 \%$ of the cell performance with hydrogen: the maximum current density for hydrogen was $316 \mathrm{~mA} \mathrm{~cm}^{-2}$ and $220 \mathrm{~mA} \mathrm{~cm}^{-2}$ for JP-8, corresponding to a maximum power density of $153 \mathrm{~mW} \mathrm{~cm}^{-2}$ and $120 \mathrm{~mW} \mathrm{~cm}^{-2}$ respectively. In terms of durability, Gen 3.1 with JP-8 demonstrated an average efficiency of $41.3 \%$ at $76 \mathrm{~mW}$ $\mathrm{cm}^{-2}$ for 1 hour. The whole durability test is illustrated in Figure 7 (right). The next generation of cells aims to reach $>200 \mathrm{~mW} \mathrm{~cm}^{-2}$ power density with the military fuels. To achieve this a more detailed evaluation of separator properties such as porosity and stability for long-term operation is still needed [12]. It has been pointed out that interactions between the liquid tin anode and fuel have not been systematically studied and that better modelling and a fundamental study is needed.

Direct conversion of biodiesel has been demonstrated using the LTA SOFC [5]. In an approach similar to that adopted for JP-8, a tubular LTA SOFC cell was tested for $4.5 \mathrm{~h}$ with biodiesel (B100) prepared from virgin and waste cooking oils [5]. Peak power and current density values of $117 \mathrm{~mW} \mathrm{~cm}^{-2}$ and $217 \mathrm{~mA} \mathrm{~cm}^{-2}$ and overall cell efficiency of $40 \%$ were reported. The results of the study also verify the fuel flexibility of the LTA SOCF system.

An interesting approach of using a separate electrochemical reactor coupled to an external chemical reactor with liquid tin anode SOFC was recently proposed by Colet Lagrille et al. [26]. The system oxidizes carbon directly in fuel cell mode and produces $\mathrm{H}_{2}$ in the electrolyser mode. The schematic of two separate reactors is illustrated in Figure 8. The approach has the advantage of allowing the 'combustion' (fuel oxidation) process and the electrochemical oxidation of the melt to be optimized in two separate reactors; and it also improves mass transport losses. The disadvantage is that pumping of liquid metal between the reactors is necessary. 


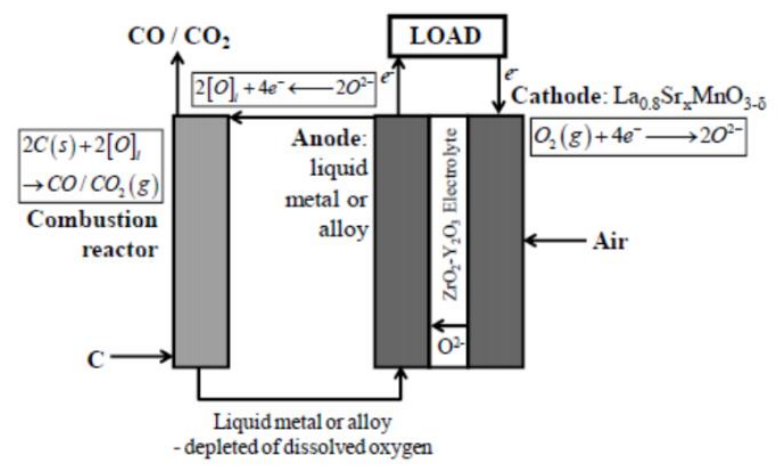

(a)

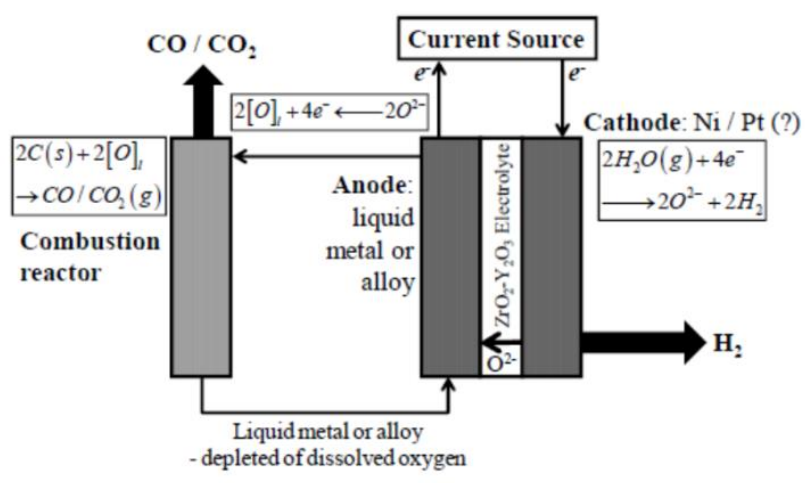

(b)

Figure 8. (a) Schematic of a LMA SOFC coupled to an external combustion reactor,

(b) Schematic of a LMA Solid Oxide Electrolyser (SOE) coupled to an external combustion reactor [26]

This study also reports a 2D model of a micro-tubular hollow fiber fuel cell to predict distribution of oxygen concentration within the liquid tin anode [26]. The diffusion coefficient of oxygen in tin was assumed, the authors highlighted the need for accurate determination of this parameter for reliable model prediction.

\section{Alternative metals and metal-alloy anodes for LME SOFC}

Other metals and metal alloys have been demonstrated as interesting anode materials capable of direct carbon oxidation in novel SOFCs. As summarised earlier in Table 2, the most common liquid metal anodes are made of: tin, bismuth, antimony, lead, copper, as well as indium and silver.

\section{Liquid Copper Anode SOFCs}

Successful performance of LME direct carbon fuel cell (DCFC) has been demonstrated using a molten copper anode operating at $1373 \mathrm{~K}$ [21]. The overall conversion efficiency measured at maximum power density was $62.5 \%$.

Design of this system was different to those discussed earlier in the way that the cathodesupported YSZ tube was immersed into liquid copper media. Figure 9(a) shows the schematic presentation of the system [Pt, Cr Cermet, $\mathrm{Cu}-\mathrm{O}(\mathrm{I})+\mathrm{C} / /\left(\mathrm{Y}_{2} \mathrm{O}_{3}\right) \mathrm{ZrO}_{2} / / \mathrm{La}_{0.9} \mathrm{Sr}_{0.1}(\mathrm{Mn}, \mathrm{Fe}, \mathrm{Co}) \mathrm{O}_{3-\delta} \mathrm{O}_{2}$ (air), Pt]. The fuel (coke particles) was added via an alumina inlet tube and stirred thoroughly with a stirrer; the entire cell was suspended in a vertical furnace. The OCV of the system was measured to be $1.2 \mathrm{~V}$, and generated a maximum power density of $1.7 \mathrm{~W} \mathrm{~cm}^{-2}\left(2.25 \mathrm{~A} \mathrm{~cm}^{-2}\right.$ at $\left.0.75 \mathrm{~V}\right)$ as shown in Figure $9(\mathrm{~b})$.

Despite good overall performance, liquid copper SOFCs are still difficult to operate. The relatively high vapour pressure of copper, compared to tin and other metals, is a challenge for practical operation. In addition, copper anodes necessitate very high operating temperatures (m.p. = $1357.8 \mathrm{~K}$ ), which inevitably complicates operation of the system. 


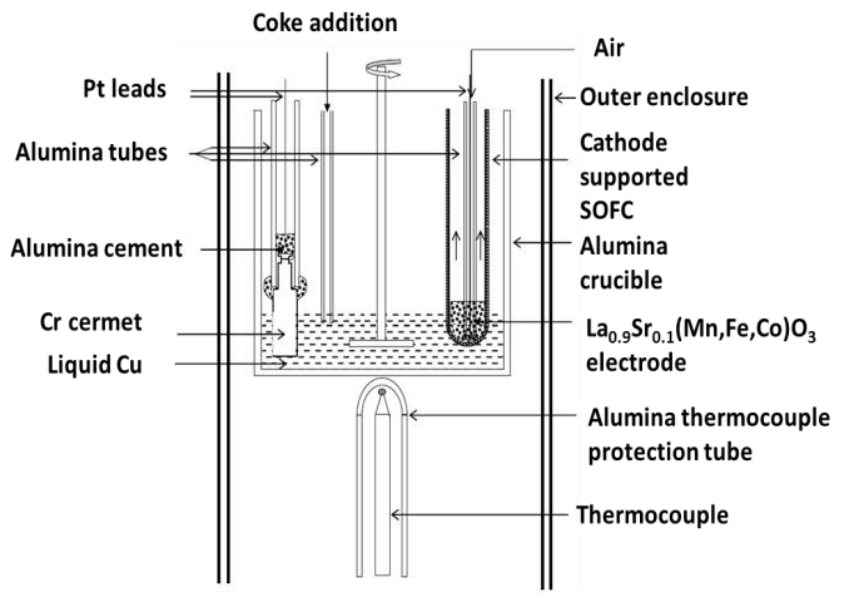

(a)

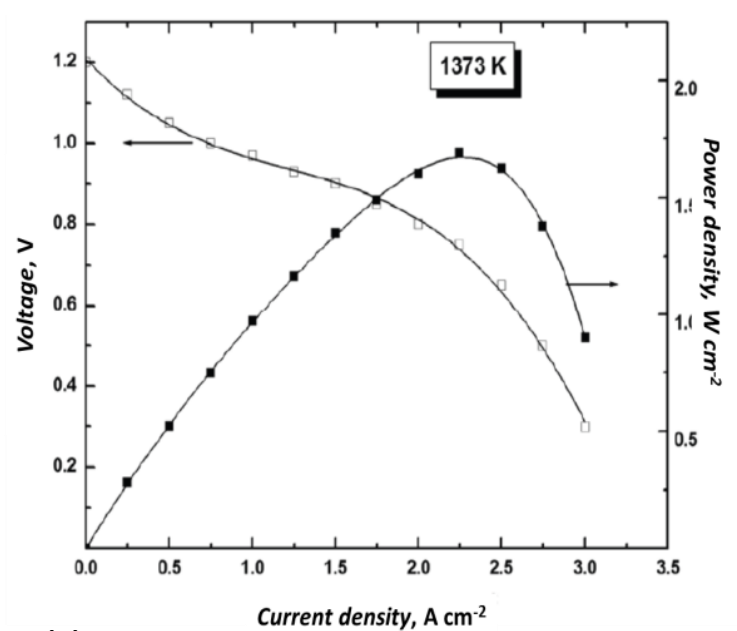

(b)

Figure 9: (a) Schematic of liquid copper anode SOFC,

(b) Polarisation and power density curves for liquid copper anode SOFC[21]

\section{Liquid antimony}

Liquid antimony has been assessed as an anode for DCFCs [29]. Operating at $973 \mathrm{~K}$ and employing a Sc-stabilized zirconia (ScSZ) electrolyte, the system, incorporating an air electrode but with no input of fuel, has demonstrated an open-circuit voltage (OCV) of $0.75 \mathrm{~V}$ for the redox couple $\mathrm{Sb}-\mathrm{Sb}_{2} \mathrm{O}_{3}$. Having an anode electrode resistance of $0.06 \Omega \mathrm{cm}^{2}$, the operated power density was $350 \mathrm{~mW} \mathrm{~cm}^{-2}$. As expected, the addition of sugar char immediately increased the cell voltage as the $\mathrm{Sb}_{2} \mathrm{O}_{3}$ was reduced with fuel, preventing formation of a metal oxide layer on the electrolyte surface. Scaling up of such liquid antimony DCFC technology may require an increase in the rate of reaction between fuels and antimony oxide, as some carbonaceous fuels (carbon black, rice starch) have not demonstrated any interaction with liquid Sb [29].

\section{Liquid bismuth}

Liquid bismuth has been reported to have an inferior performance to tin anodes [25]. The OCV was reported to be slightly lower than theoretical $(440 \mathrm{mV}): 424 \mathrm{mV}$ with hydrogen supplied and $408 \mathrm{mV}$ without [25]. Being ion-conductive, bismuth oxide may solve the problem with oxide transport blockage through YSZ-anode media [26]. However, operating at lower power densities, liquid bismuth SOFCs require in-depth investigation and are not considered to be a feasible alternative to SOFCs with a tin anode $[21,22]$.

\section{Other metal anodes for LME SOFCS}

Indium (In), lead ( $\mathrm{Pb})$, antimony (Sb) [23] and silver ( $\mathrm{Ag}$ ) [30] have also been examined in battery and fuel cell modes (if feasible) to test their anodic efficiency in LME SOFCs. Similar to tin, the performance of indium was adversely affected by formation of metal oxide at the electrolyte interface when higher current was drawn. This was not the case for $\mathrm{Pb}$ and $\mathrm{Sb}$, where the melting points of their metal oxides were lower than the operating temperature. Direct oxidation of coal has also been proposed to operate in a liquid iron anode SOFC [31].

The application of a liquid silver anode for DCFCs has been experimentally explored by Javadekar [30] who achieved an OCV of $1.12 \mathrm{~V}$ with charcoal. Liquid silver has lower melting point and higher oxide solubility compared to other metals (e.g. copper) and therefore is advantageous. Another approach was to use a Ag-Sb alloy, where the high solubility of oxide in silver might be combined with the low melting point of $\mathrm{Sb}$, to improve overall anode performance [30]. 


\section{Metal alloy anodes}

In an effort to optimize anode properties, various alloy systems have been investigated. The work involving the pure metal anodes (bismuth) mentioned above was developed further to explore anodes of liquid tin-lead and liquid tin-lead-bismuth alloys in battery mode followed by direct oxidation of coal [25]. For the tin-lead alloy, performance degradation (from $11.7 \mathrm{~mW} \mathrm{~cm}^{-2}$ to $10.1 \mathrm{~mW} \mathrm{~cm}^{-2}$ ) occurred within 13 hours, with an increase in performance to $14 \mathrm{~mW} \mathrm{~cm}^{-2}$ when coal was introduced. The addition of bismuth to tin-lead alloy decreased the overall anode effectiveness.

\section{Uncertainties and technological challenges of LME SOFC}

Prior to commercialization of liquid metal anode solid oxide fuel cells, greater understanding of the electrochemical reactions, redox and transport processes within liquid metal electrodes is needed [20]. The following research challenges are particularly highlighted: the nature of oxidised species in liquid metal electrode media; transport of oxygen or oxidized species in LME SOFC; reaction kinetics between oxide and fuel within liquid anode; kinetics of oxygen transfer at liquid metal anode - electrolyte interface; oxygen (oxide) diffusivity / transport through liquid metal layer and solubility of oxide and fuels in the melt.

As argued by Abernathy et al. [4], improvement of oxygen transport within liquid metal media can be achieved by increasing oxygen solubility through alloying. Wetting characteristics of liquid metal with the electrolyte and fuel oxidation kinetics need also to be considered.

Most of the work so far has been focused on the testing of single cells, which limits its further application. In this regard, it would be beneficial to model the performance of LME SOFCs stacks and prototype based on derived design guidelines.

In order to be able to model and later design practical LME SOFC systems the information on oxygen solubility and transport in liquid metals is essential as it is a central process that may limit the performance of the fuel cell. Fundamental investigation of these interactions within a liquid anode, as well as analysis of other physical metal properties with temperature (e.g. vapour pressure, melting point, surface tension, contact angle, etc.) will be beneficial in designing and building durable and stable fuel cells.

Other important factors requiring investigation include: aspects concerned with the introduction of solid fuel into the melt; optimization of thickness of the melt; prevention of unfavorable formation of metal oxide tending to result in blocking of the electrolyte; fundamental studies concerned with transportation of the oxide from the generation zone at the interface with the electrolyte to the reaction zone at the interface with the fuel (relevant aspects include melt thickness, diffusion of oxidised species and convection in the melt); effect and optimization (which may include surface structuring) of contact area between the liquid anode and electrolyte.

Engineering considerations include: matching of electrolyte composition to temperature of operation; choice of electrolyte thickness based upon optimization between mechanical properties and ionic conductivity; agitation of the melt; generation of suitable electrolyte surface structures; cell design; scale-up of laboratory cells to pilot and then to commercial plant.

\section{Conclusions}

LMA SOFCs are a highly efficient option for direct electrochemical conversion of solid fuels into electrical energy. A range of possible metal anodes have been reviewed with tin the material on which most development work has been performed. Despite numerous studies, the understanding 
of the reaction kinetics at liquid metal-fuel and liquid metal-electrolyte interfaces, as well as oxygen diffusivity through the liquid metal layer needs further systematic investigation.

Acknowledgements: The authors wish to thank Nazarbayev University and the Government of Republic of Kazakhstan for the BOLASHAK International Scholarship for Aliya Toleuova and the EPSRC Supergen Fuel Cells programme (EP/G030995/1) for supporting Brett's research.

\section{References}

[1] International Energy Agency, World Energy Outlook 2010.

[2] C. Gough, S. Shackley, UK Technical report 47 (2005) 1-256.

[3] D. Cao, Y. Sun, G. Wang, J. Power Sources 167 (2007) 250-257.

[4] H. Abernathy, R. Gemmen, K. Gerdes, M. T. Koslowske, T. Tao, J. Power Sources 196 (2011) 4564-4572.

[5] W. A. McPhee, M. Boucher, J. Stuart, R. S. Parnas, M. T. Koslowske, T. Tao, B. A. Wilhite, Energy Fuels 23 (2009) 5036-5041.

[6] T. Tao, M. T. Koslowske, W. A. McPhee, L. S. Bateman, M. J. Slaney, J. Bentley, Coal Based Fuel Cell Technology: Status, Needs and Future Applications, Liquid Tin Anode Solid Oxide Fuel Cell for Direct Conversion of Carbon Based Fuels Including Coal, Morgantown WV, USA, 2007, p. 93-103.

[7] T. Tao, M.T. Koslowske, J. Bentley, 219th ECS Meetings, Liquid Tin Anode SOFC for Direct Fuel Conversion - Cell, Stack and System Development, Montreal, Canada, 2011, abstract No.820.

[8] S. Singhal, K. Kendall, High Temperature Solid Oxide Fuel Cells Fundamentals, Design and Applications, Elsevier, Oxford, UK, 2003, p. 89-92.

[9] T. S. Li, W. G. Wang, J. Power Sources 196 (2011) 2066-2069.

[10] D. J. Brett, M. N. Manage, E. Agante, N. P. Brandon, E. R. Brightman, J. C. Brown, I. Staffell, in Functional materials for sustainable energy applications, J. A. Kilner, S. J. Skinner, S. J. Irvine, P. P. Edwards, Woodhead Publishing Limited, Cambridge, UK, 2012, p. 249-274.

[11] T. Tao, L.S. Bateman, J. Bentley, M. J. Slaney, ECS Trans. 5 (2007) 463-472.

[12] T. Tao, W. A. McPhee, M. T. Koslowske, L. S. Bateman, M. J. Slaney, J. Bentley, ECS Trans. 12 (2008) 681-690.

[13] T. Tao, M. J. Slaney, L. S. Bateman, J. Bentley, ECS Trans. 7 (2007) 1389-1397.

[14] R. O'Hayre, S. Cha, W. Colella, F. B. Prinz, Fuel Cell Fundamentals, John Wiley \& Sons, New Jersey,USA, 2006, p. 10-12.

[15] S. Kakac, A. Pramuanjaroenkij, X. Y. Zhou, Int. J. Hydrogen Energy 32 (2007) 761-786.

[16] Energy Efficiency \& Renewable Energy, http://www1.eere.energy.gov/hydrogenandfuelcells/fuelcells/pdfs/fc_comparison_chart.pdf (accessed on 1.12.2012).

[17] M. N. Manage, D. Hodgson, N. Milligan, S. J. Simons, D. J. Brett, Int. J. Hydrogen Energy 36 (2011) 5782-5796.

[18] N. P. Brandon, D. J. Brett, Philos. Trans. R. Soc. London, Ser. A 364 (2006) 147-159.

[19] P. R. Shearing, D. J. Brett, N. P. Brandon, Int. Mater. Rev. 55 (2010) 347-363.

[20] R. Gemmen, H. Abernathy, K. Gerdes, M. T. Koslowske, W. A. McPhee, T. Tao, in Advances in Solid Oxide Fuel Cells V, N. P. Bansal, P. Singh, John Wiley \& Sons, New Jersey, USA, 2009, p. 37-52.

[21] K. T. Jacob, ECS Trans. 35 (2011) 573-582.

[22] A. Javadekar, A. Jayakumar, R. J. Gorte, J. M. Vohs, D. J. Buttrey, J. Electrochem. Soc. 159 (2012) A386-A389.

[23] A. Jayakumar, J. M. Vohs, R. J. Gorte, Ind. Eng.Chem. Res. 49 (2010) 10237-10241. 
[24] A. Jayakumar, S. Lee, A. Hornés, J. M. Vohs, R. J. Gorte, J. Electrochem. Soc. 157 (2010) B365-B369.

[25] M. LaBarbera, M. Fedkin, S. Lvov, ECS Trans. 35 (2011) 2725-2734.

[26] M. Colet Lagrille, U. Doraswami, G. H. Kelsall, ECS Trans. 42 (2012) 137-148.

[27] T. Tao, M. T. Koslowske, J. Bentley, J. Brodie, C. MacKean, ECS Trans. 41 (2012) 125-135.

[28] S. C. Rayman, M. T. Koslowske, L. S. Bateman, T. Tao, R. E. White, ECS Trans. 33 (2011) 93121.

[29] A. Jayakumar, R. Küngas, S. Roy, A. Javadekar, D. J. Buttrey, J. M. Vohs, R. J. Gorte, Energy Environ. Sci. 4 (2011) 4133-4137.

[30] A. D. Javadekar, Ph.D. Thesis, University of Delaware (2012).

[31] I. V. Yentekakis, P. G. Debenedetti, B. Costa, M. Konsolakis, V. Kiousis, Ionics, 5 (1999) 460471.

(C) 2013 by the authors; licensee IAPC, Zagreb, Croatia. This article is an open-access article distributed under the terms and conditions of the Creative Commons Attribution license (http://creativecommons.org/licenses/by/3.0/) 